\title{
A prospective study to assess role of serum lactate dehydrogenase in prediction of adverse outcomes of pre-eclampsia and eclampsia
}

\author{
Jyoti Jharia, Pooja Mathur*, Anupama Dave, Poonam Mathur
}

Department of Obstetrics and Gynaecology, MGM medical College and MY hospital, Indore, India

Received: 23 June 2016

Revised: 08 July 2016

Accepted: 12 July 2016

\section{*Correspondence:}

Dr. Pooja Mathur,

E-mail: poojamathur2604@gmail.com

Copyright: ( ) the author(s), publisher and licensee Medip Academy. This is an open-access article distributed under the terms of the Creative Commons Attribution Non-Commercial License, which permits unrestricted non-commercial use, distribution, and reproduction in any medium, provided the original work is properly cited.

\section{ABSTRACT}

Background: Pregnancy induced hypertension is one of the most dreaded complication in developing countries. The purpose of this study is to evaluate incidence, risk factors and complications of pre-eclampsia and eclampsia and its relation to serum $\mathrm{LDH}$ levels. This was done with a view to making recommendations towards furtherance of objectives of this initiative.

Methods: 380 patients with diagnosed eclampsia and preeclampsia were included based on a proforma.

Results: Higher grades of proteinuria, higher BP and serum LDH levels $>600$ IU/L are significantly associated with adverse maternal and fetal outcome.

Conclusions: LDH co-relates with adversity of maternal and fetal outcome in eclampsia and pre-eclampsia.

Keywords: Pre-eclampsia, Eclampsia, Serum LDH levels, Prediction, Outcome

\section{INTRODUCTION}

Eclampsia, which is considered a complication of severe preeclampsia, is commonly defined as new onset of grand mal seizure activity and/or unexplained coma during pregnancy or postpartum in a woman with signs or symptoms of preeclampsia. ${ }^{2}$

It typically occurs during or after the $20^{\text {th }}$ week of gestation or in the postpartum period. Nonetheless, eclampsia in the absence of hypertension with proteinuria has been demonstrated to occur in $38 \%$ of cases reported in the United Kingdom. ${ }^{3}$ Similarly, hypertension was absent in $16 \%$ of cases reviewed in the United States. ${ }^{4}$

The clinical manifestations of maternal preeclampsia are hypertension and proteinuria with or without coexisting systemic abnormalities involving the kidneys, liver, or blood. There is also a fetal manifestation of preeclampsia involving fetal growth restriction, reduced amniotic fluid, and abnormal fetal oxygenation. ${ }^{2}$ HELLP syndrome is a severe form of preeclampsia and involves hemolytic anemia, elevated liver function tests (LFTs), and low platelet count.

Most cases of eclampsia present in the third trimester of pregnancy, with about $80 \%$ of eclamptic seizures occurring intrapartum or within the first 48 hours following delivery.

Rare cases have been reported before 20 weeks' gestation or as late as 23 days' postpartum. Other than early detection of preeclampsia, no reliable test or symptom complex predicts the development of eclampsia. In developed countries, many reported cases have been classified as unpreventable.

\section{Pathophysiology of eclampsia}

Factors contribute to pathology of eclampsia

- Inhibition of uterovascular development. 
- Hindrance of cerebral blood flow regulation.

- Endothelial dysfunction.

- Hypoxia and lactate production in trophoblast cells. ${ }^{8}$

In normal tissues, hypoxia increases metabolic pathways, such as glycolysis. High glucose consumption and lactate production is normally present in the human placenta and it has been accepted that glycolysis is its baseline, major energy pathway. ${ }^{9,10}$ Hypoxia, if encountered in preeclampsia, will further enhance glycolysis and increase the activity of lactate dehydrogenase which converts pyruvate to lactate.

Lactate dehydrogenase activity and gene expression are higher in placentas from pre-eclamptic pregnancies compared to normal pregnancies. ${ }^{11}$

The biological consequences of increased lactate levels within the placenta resulting from increased lactate dehydrogenase activity in preeclampsia are unknown. Lactate could serve as a signaling compound to coordinate cell and systemic function. For example, it could serve as fuel for the fetus within the hypoxic environment through glucose generation. ${ }^{12,13}$

Hypoxia induces LDH isozyme activity in trophoblasts resulting in higher lactate production. Primary human trophoblast cells demonstrated an increase in LDHA mRNA when exposed to hypoxic conditions confirming LDHA isozyme presence in placental trophoblasts and their response to hypoxia. In mammals, two genes code for LDHA and LDHB subunits that give rise to five tetrameric LDH isozymes (LDHA4, LDHA3B, LDHA2B2, LDHAB3, LDHB4) ${ }^{32}$. This behavior suggests increased LDHA gene expression and activity in placentas from preeclampsia patients are due to hypoxia and that the trophoblast cells could be sensitive to that stress. Placentas from women with preeclampsia exhibited an increased level of LDHA4 isozyme activity and mRNA expression compared to placentas from normal pregnancies. LDHA4 is the isozyme most responsive to hypoxia because the LDHA gene is transcriptionally regulated by HIF1a. ${ }^{16}$ LDHA4 isozyme activity, LDHA gene and LDHA protein expression are increased as a result of hypoxia.

HIF1a, a transcription factor that binds to the LDH gene, is also increased in gene expression, possibly through the induction of oxidative stress since reactive oxygen species have been implicated in the stabilization and action of HIF1a. However, LDHB transcription does not appear to be co-regulated as its mRNA levels decrease while the LDHB protein level remains constant. LDHA4 and B4 isozymes are key players in glycolysis, the pathway in which the final step is conversion of pyruvate to lactate.

\section{Outcome}

Five percent of patients with hypertension develop severe preeclampsia, and about $25 \%$ of women with eclampsia have hypertension in subsequent pregnancies. About $2 \%$ of women with eclampsia develop eclampsia with future pregnancies.

Multiparous women with eclampsia have a higher risk for the development of essential hypertension; they also have a higher mortality rate in subsequent pregnancies than do primiparous women

\section{Maternal morbidity}

- Maternal complications from eclampsia

- Permanent CNS damage from recurrent seizures or intracranial bleeds

- Disseminated intravascular coagulopathy

- Renal insufficiency

- Pulmonary edema

- Cardiopulmonary arrest

The most significant maternal complication of eclampsia is permanent CNS damage secondary to recurrent seizures or intracranial bleeding. The maternal mortality rate is $8-36 \%$ in these cases. ${ }^{17}$

\section{Maternal mortality}

Eclampsia and preeclampsia account for approximately 63,000 maternal deaths annually worldwide. ${ }^{22}$ In developed countries, the maternal death rate is reportedly $0-1.8 \%$. The perinatal mortality rate from eclampsia in the United States and Great Britain, ranges from 5.6\% to $11.8 \%$. The maternal mortality rate is as high as $14 \%$ in developing countries. $4,18,19$

A study from the US centers for disease control and prevention (CDC) found an overall preeclampsia/eclampsia case-fatality rate of 6.4 per 10,000 cases at delivery. The study also found a particularly high risk of maternal death at 20-28 weeks' gestation. ${ }^{20} \mathrm{~A}$ majority of women who suffer eclampsiaassociated death have concurrent HELLP syndrome. ${ }^{22}$

\section{Fetal/neonatal mortality}

The fetal mortality rate varies from $13-30 \%$ due to premature delivery and its complications. Placental infarcts, abruptio placentae, intrauterine growth retardation, and fetal hypoxia also contribute to fetal demise.

\section{METHODS}

The study was carried out in the department of obstetrics and gynaecology at a tertiary care hospital and was a 
prospective study. The study period extended from August 2011 to July 2012.

\section{Selection of cases}

The patients were selected from those who were admitted as emergency cases in labour room, irrespective of age and parity. On a specially designed proforma for this study, the patient particulars like detailed obstetric history, examination and laboratory findings were recorded.

\section{Study group}

\section{Inclusion criteria}

- All cases of pre eclampsia and eclampsia admitted in the department of obstetrics and gynaecology.

- All proven cases of eclampsia (hypertension, albumin and convulsion).

- All cases of imminent eclampsia.

\section{Exclusion criteria}

- Known case of epilepsy.

- Convulsion occurring as a complication of uremia

- Convulsion or coma due to cerebral disease, eg. Encephalitis, meningitis, cysticercosis, ruptured cerebral Aneurysm.

\section{Methodology}

The cases were studied according to a proforma

\section{The evaluated parameters}

\section{- $\quad$ Booking status}

Patients with 3 or more antenatal visits at M.Y. Hospital or private clinics were taken as booked cases.

\section{- Blood pressure recording}

Blood pressure was recorded in lateral recurrent position. The point of muffing of Korotkoff's sound was taken as diastolic pressure when the sound failed to disappear till zero, otherwise the point of disappearance of Korotkoff's sound was taken as diastolic BP. At least two recording six hours apart were taken.

\section{- Family history of PIH}

\section{- Proteinuria}

A test tube was two third filled with a midstream sample of urine. The top $2 \mathrm{~cm}$ of the urine was boiled over a flame. Turbidity of urine which did not disappear even on addition of $10 \%$ acetic acid was considered to be indication of proteinuria. For practical purposes the amount of protein was expressed as a haze $(+)$, cloud $(++)$ or granular precipitate $(+++)$. Confirmation was achieved by 24 hour urine protein.

\section{- Fundus examination}

Inpatient bedside referral was attended by the ophthalmology department.

- Haematologic parameters.

- Liver function test.

- Renal function test.

\section{RESULTS}

The present study was carried out on 380 cases, admitted in the department of obstetrics and gynaecology at a tertiary care hospital. These cases were studied thoroughly regarding incidence, demographic characteristics, presenting signs and symptoms, blood pressure on admission, laboratory finding, complications, maternal death, neonatal weight and fetal outcome.

Table 1: Distribution of cases according to diagnosis.

\begin{tabular}{|lllll|}
\hline $\begin{array}{l}\text { Diagnosis on } \\
\text { admission }\end{array}$ & $\begin{array}{l}\text { No. of } \\
\text { Cases }\end{array}$ & Percent & $\begin{array}{l}\text { No. of } \\
\text { Death }\end{array}$ & $\begin{array}{l}\text { Percentage } \\
\text { mortality }\end{array}$ \\
\hline Preeclampsia & 120 & 31.58 & 12 & 12 \\
\hline Eclampsia & 260 & 68.42 & 23 & 8.84 \\
\hline Total & $\mathbf{3 8 0}$ & $\mathbf{1 0 0 \%}$ & $\mathbf{3 5}$ & $\mathbf{9 . 2 1 \%}$ \\
\hline
\end{tabular}

Table 2: Distribution of preeclampsia and eclampsia cases according to systolic blood pressure ( $\mathrm{mmHg}$ ).

\begin{tabular}{|l|llll|}
\hline $\begin{array}{l}\text { Systolic blood } \\
\text { pressure (mm Hg) }\end{array}$ & \multicolumn{2}{c|}{ Preeclampsia } & \multicolumn{2}{l|}{ Eclampsia } \\
\hline$>150$ & No. & $\mathbf{\%}$ & No. & \% \\
\hline$<150$ & 84 & $70.00 \%$ & 212 & 81.54 \\
\hline Total & 36 & $30.00 \%$ & 48 & 18.46 \\
\hline & 120 & $100 \%$ & 260 & $100 \%$ \\
\hline \multirow{2}{*}{ Systolic BP } & Case & Mean & SD & P \\
\cline { 2 - 6 } & Preeclampsia & 170.50 & 12.55 & 0.217 \\
\cline { 2 - 6 } & Eclampsia & 168.35 & 17.06 & 0.168 \\
\hline
\end{tabular}

Table 3: Distribution of preeclampsia and eclampsia cases according to diastolic blood pressure ( $\mathrm{mmHg}$ ).

\begin{tabular}{|c|c|c|c|c|c|}
\hline \multirow{2}{*}{\multicolumn{2}{|c|}{$\begin{array}{l}\text { Diastolic Blood } \\
\text { Pressure } \\
(\mathrm{mmHg})\end{array}$}} & \multicolumn{2}{|c|}{ Preeclampsia } & \multicolumn{2}{|c|}{ Eclampsia } \\
\hline & & No. & $\%$ & No. & $\%$ \\
\hline$>110$ & & 72 & 60.00 & 208 & 80.00 \\
\hline$<110$ & & 48 & 40.00 & 52 & 20.00 \\
\hline Total & & 120 & $100 \%$ & 260 & $100 \%$ \\
\hline \multirow{3}{*}{ Diastolic BP } & $\mathbf{C a}$ & & Mean & SD & P value \\
\hline & Pre & ampsia & 115.50 & 9.6 & 0.104 \\
\hline & $\mathrm{Ecl}$ & psia & 117.23 & 9.5 & 0.106 \\
\hline
\end{tabular}


Table 4: Grading of consciousness according to GCS. (glass glow coma scale).

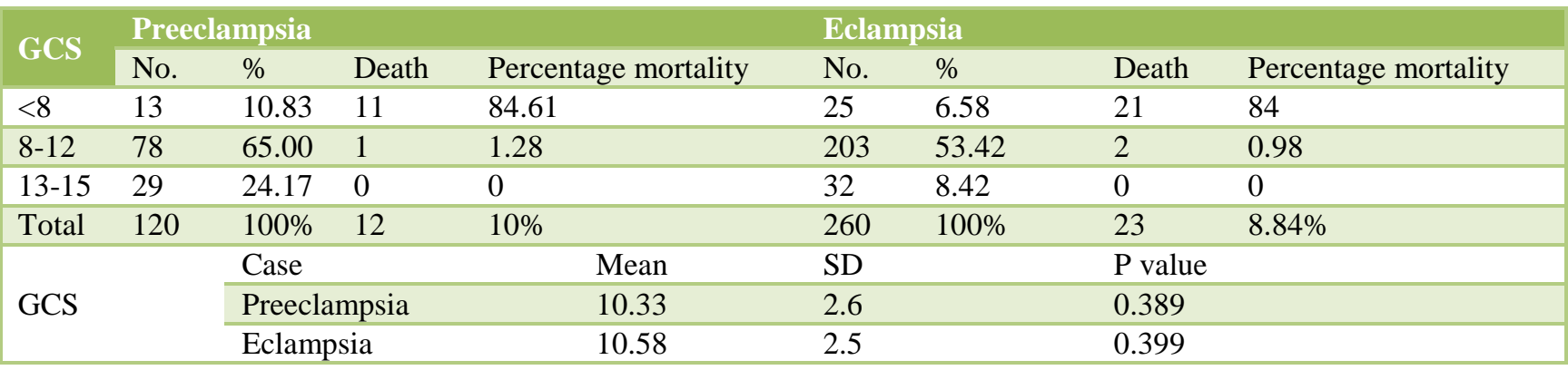

Table 5: Distribution of cases on the basis of severity of proteinuria.

\begin{tabular}{|c|c|c|c|c|c|c|c|c|}
\hline \multirow[b]{2}{*}{ Urine albumin } & \multicolumn{4}{|c|}{ Preeclampsia } & \multicolumn{4}{|c|}{ Eclampsia } \\
\hline & No. & $\%$ & Death & $\begin{array}{l}\text { Percentage } \\
\text { mortality }\end{array}$ & No. & $\%$ & Death & $\begin{array}{l}\text { Percentage } \\
\text { mortality }\end{array}$ \\
\hline Traces & 0 & 0.00 & 0 & 0.00 & 0 & 0.00 & 0 & 0.00 \\
\hline $1+$ & 13 & 10.83 & 1 & 7.69 & 42 & 16.15 & 1 & 2.38 \\
\hline $2+$ & 36 & 30.00 & 2 & 5.55 & 58 & 22.31 & 2 & 3.44 \\
\hline $3+$ & 48 & 40.00 & 7 & 14.58 & 82 & 31.54 & 13 & 15.85 \\
\hline $4+$ & 22 & 18.33 & 2 & 9.09 & 78 & 30.00 & 7 & 8.97 \\
\hline Total & 120 & $100 \%$ & 12 & $10 \%$ & 260 & $100 \%$ & 23 & $8.84 \%$ \\
\hline
\end{tabular}

Table 6: Distribution of cases showing lactate dehydrogenase level (LDH) on admission.

\begin{tabular}{|c|c|c|c|c|c|c|c|c|c|}
\hline \multirow{2}{*}{$\begin{array}{l}\text { LDH } \\
\text { (IU/L) }\end{array}$} & \multicolumn{5}{|c|}{ Preeclampsia } & \multicolumn{4}{|c|}{ Eclampsia } \\
\hline & No. & $\%$ & Death & Percent & mortality & No. & $\%$ & Death & Percentage mortality \\
\hline$<600$ & 27 & 22.50 & 1 & 3.70 & & 56 & 21.54 & 2 & 3.57 \\
\hline$>600$ & 93 & 77.50 & 11 & 11.82 & & 204 & 78.46 & 21 & 10.29 \\
\hline TOTAL & 120 & $100 \%$ & 12 & 10 & & 260 & $100 \%$ & 23 & 8.84 \\
\hline \multirow{3}{*}{ LDH } & \multirow{2}{*}{\multicolumn{3}{|c|}{$\begin{array}{l}\text { Case } \\
\text { Preeclamnsia }\end{array}$}} & \multicolumn{3}{|c|}{ Mean } & \multicolumn{2}{|l|}{ SD } & $P$ value \\
\hline & & \multirow{2}{*}{\multicolumn{2}{|c|}{ Preeclampsia }} & \multicolumn{3}{|c|}{725.81} & \multicolumn{2}{|l|}{195.92} & 0.181 \\
\hline & Eclampsia & & & \multicolumn{3}{|c|}{758.77} & \multicolumn{2}{|l|}{234.80} & 0.154 \\
\hline
\end{tabular}

Table 7: Perinatal outcome according to LDH level (IU/L).

\begin{tabular}{|c|c|c|c|c|c|c|c|c|}
\hline \multirow{3}{*}{ LDH (perinatal outcome) } & \multicolumn{4}{|c|}{ Preeclampsia (N=120) } & \multicolumn{4}{|c|}{ Eclampsia $(N=260)$} \\
\hline & \multicolumn{2}{|c|}{$<600(\mathrm{IU} / \mathrm{L})$} & \multicolumn{2}{|c|}{$>600(\mathrm{IU} / \mathrm{L})$} & \multicolumn{2}{|c|}{$<600(\mathrm{IU} / \mathrm{L})$} & \multicolumn{2}{|c|}{$>600(\mathrm{IU} / \mathrm{L})$} \\
\hline & No. & $\%$ & No. & $\%$ & No. & $\%$ & No. & $\%$ \\
\hline Healthy baby & 32 & 26.67 & 11 & 9.2 & 75 & 28.85 & 23 & 8.85 \\
\hline Sick Baby & 8 & 6.69 & 44 & 36.67 & 17 & 6.54 & 96 & 36.92 \\
\hline IUD & 7 & 5.834 & 17 & 14.17 & 5 & 1.93 & 36 & 13.85 \\
\hline \multirow{2}{*}{ Mother died undelivered } & 1 & 0.84 & 0 & 0 & 2 & 0.76 & 6 & 2.30 \\
\hline & \multicolumn{4}{|c|}{ Total 120 Percentage $100 \%$} & \multicolumn{4}{|c|}{ Total 260 Percentage $100 \%$} \\
\hline
\end{tabular}

\section{DISCUSSION}

Patients were divided into preeclamptic, eclamptic groups containing 120, and 260 patients respectively. Statistical analysis done with SPSS-17 programme. Variables are described first then compared with three groups using Chi-square test. P-value $<0.05$ were considered significant.

\section{Incidence}

Incidence of eclampsia varies from country to country. In general eclampsia is preventable and it less common in the developed countries Swains et al reported the incidence of eclampsia as $2.2 \%$ of all hospital deliveries. $^{23}$ 
Choudhary P. et al (mid April 2000 to mid April 2001) in a retrospective study observed the incidence of eclampsia as 2.9 per 1000 deliveries. $^{24}$
Tayyiba $\mathrm{W}$ et al reported the incidence of eclampsia at Lahore General Hospital (2002) as 2.2\%. ${ }^{30}$

Table 8: Distribution of birth weight according to LDH level (IU/L).

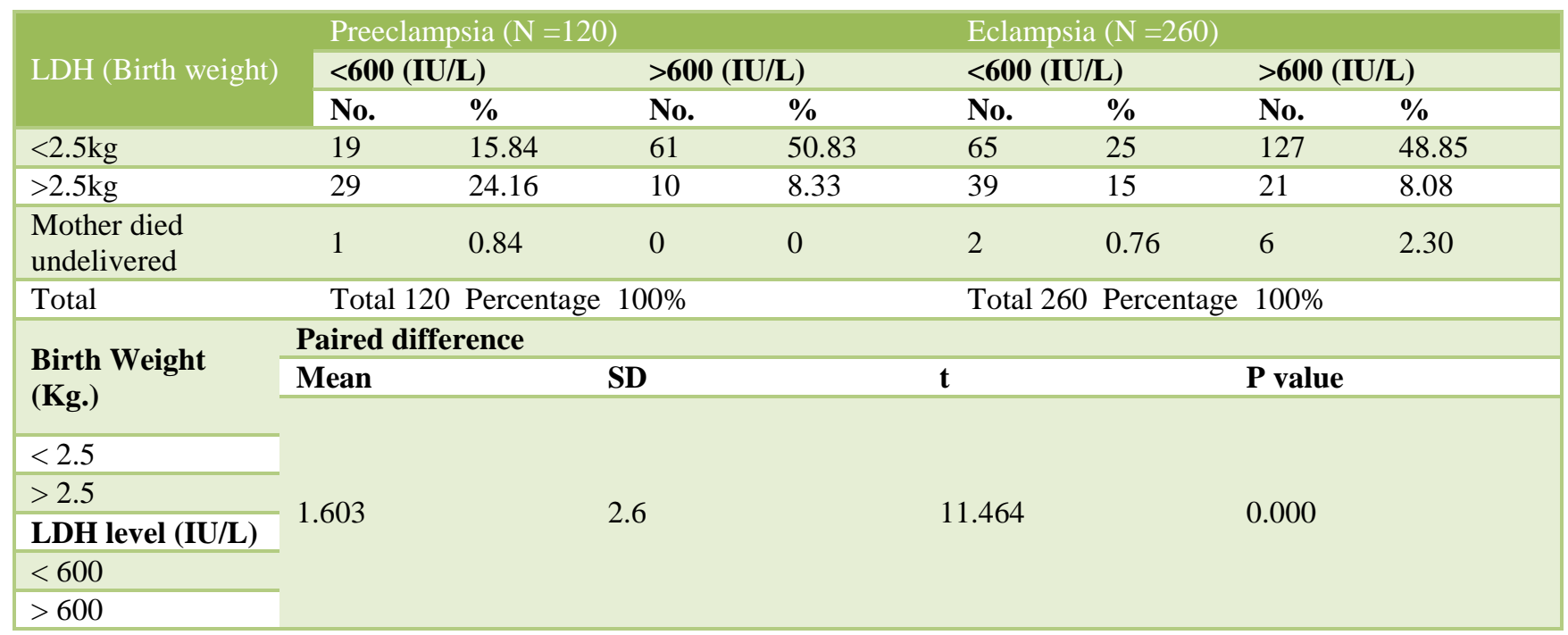

Table 9: Complications according to LDH Level (IU/L).

\begin{tabular}{|lllll|}
\hline LDH (Complications) & $<600(\mathrm{IU} / \mathrm{L})$ & $(\mathbf{N}=\mathbf{8 3})$ & $>600(\mathrm{IU} / \mathrm{L})(\mathrm{N}=297)$ & $\mathbf{\%}$ \\
\hline Abruption & $\mathbf{N o}$ & $\mathbf{\%}$ & $\mathbf{N o}$ & 17.84 \\
\hline Retinopathy & 17 & 20.48 & 53 & 40.74 \\
\hline ARF & 37 & 44.57 & 121 & 4.04 \\
\hline CVA & 0 & 0 & 12 & 1.34 \\
\hline MODS & 0 & 0 & 4 & 1.68 \\
\hline DIC & 0 & 0 & 5 & 1.34 \\
\hline Shock & 0 & 0 & 4 & 1.01 \\
\hline Died & 0 & 0 & 3 & $10.77 \%$ \\
\hline
\end{tabular}

\section{Systolic BP}

In present study it is found that systolic blood pressure on admission was proved to be $>150 \mathrm{mmHg}$. $70 \%$ of preecmaplsia and $81.54 \%$ of eclampsia had systolic $\mathrm{BP}>150 \mathrm{mmHg}$.

Aali BS et al in their study had found the systolic blood pressure on admission proved to be $>160 \mathrm{mmHg}$ in $60.5 \%$ and $66.7 \%$ of the preeclampsia and eclampsia groups respectively. ${ }^{31}$

\section{Diastolic BP}

In present study table, it is found that diastolic blood pressure on admission was proved to be $>110 \mathrm{mmHg}$ in $60 \%$ of preeclampsia and $80 \%$ of eclampsia patients.
Aali BS et al found the diastolic blood pressure on admission to be $>110 \mathrm{mmHg}$ in $49.1 \%$ of preeclampsia and $48.5 \%$ of eclampsia patients. ${ }^{31}$

\section{Glasglow coma scale}

GCS can be graded according to score as

- $\quad$ Mild: $13-15$

- Moderate: 9-12

- Severe: $<8$

In present study $17.41 \%$ of the preeclampsia and eclampsia patients had GCS less than 8 . Among these patients with GCS $<8$ had mortality of $90 \%$. This indicates that a severe derangement of GCS predicts poor outcome in these patients. Bhagwanjee et al reported GCS to be an accurate predictor of outcome in eclampsia patients. $^{25}$ 


\section{Proteinuria}

In present study about proteinuria maximum number of patients had urine protein level of $3+$ and $2+$.

Among patients who died maximum patient had urine protein level of $3+$ and urine protein level was $2+$.

\section{Serum lactate dehydrogenase}

In present study it is found that serum Lactate Dehydrogenase were $>600 \mathrm{IU} / \mathrm{L}$ in $77.50 \%$ of Preeclampsia and $78.46 \%$ of eclampsia patients.

Demir et al had found that in complicated cases of Preeclampsia and eclampsia, LDH level were significantly higher. ${ }^{16}$

Qublan HS et al had found that LDH is a biochemical marker of adverse pregnancy outcome in severe Preeclampsia patients. LDH level > $600 \mathrm{IU} / \mathrm{L}$ in $54.8 \%$ of severe Preeclampsia and $12.2 \%$ of mild Preeclampsia was seen in this study. ${ }^{28,29}$

Rinehart et al reported the rate of change of platelet count and $\mathrm{LDH}$ level in preeclampsia for $\mathrm{LDH}$, values increased at a rate of approximately 1400 IU/1 per day, $600 \mathrm{IU} / 1$ per day, $300 \mathrm{IU} / 1$ per day and $200 \mathrm{IU} / 1$ per day for patients with classes 1, 2 and 3 and for non-HELLP severe Preeclampsia, respectively. ${ }^{26}$

\section{Class I: 1400 IU/L}

Class II: 600 IU/L

Class III: 300 IU/L

Non-HELLP: 200IU/L

\section{Perinatal outcome according to LDH level}

In this study (Table 7), predominance is seen towards having a healthy baby $(26.62 \%)$ when patients have $\mathrm{LDH}$ level $<600 \mathrm{IU} / \mathrm{L}$, other outcomes were $6.69 \%$ being sick and requiring admission in nursery and $5.8 \%$ of babies being IUD. Whereas, among patients with LDH level $>600$ IU/L, only $9.2 \%$ had a healthy baby. Majority of outcomes $(36.67 \%$ were sick required admission in nursery and $14.17 \%$ IUD) were poor. Similar significant trend is seen with eclampsia patients with respect to their LDH levels. Qublan HS et al had found that $61.5 \%$ of perinatal death was found in patients having $\mathrm{LDH}$ level more than $800 \mathrm{IU} / \mathrm{L}^{28,29}$

\section{Birth weight according to LDH level}

In this study that preeclampsia patients having LDH level $<600 \mathrm{IU} / \mathrm{L}$ had $15.84 \%$ of babies with weight less than $2.5 \mathrm{~kg}$ and $24.16 \%$ of babies with weight more than $2.5 \mathrm{~kg}$ and having LDH level >600IU/L had 50.83.\% of babies with weight less than $2.5 \mathrm{~kg}$ and $8.33 \%$ of babies with weight more than $2.5 \mathrm{~kg}$. In eclampsia patients $\mathrm{LDH}$ level $<600 \mathrm{IU} / \mathrm{L}$ had $25 \%$ of babies with weight less than $2.5 \mathrm{~kg}$ and $15 \%$ of babies with weight more than $2.5 \mathrm{~kg}$. and having LDH level $>600 \mathrm{IU} / \mathrm{L}$ had $48.85 \%$ of babies with weight less than $2.5 \mathrm{~kg}$ and $8.08 \%$ of babies with weight less than $2.5 \mathrm{~kg}$ p-value is 0.00 .

Qublan HS et al had found that patient having LDH level $>800 \mathrm{IU} / \mathrm{L}$ have mean fetal weight $1821+656$ in comparison to $1849+563$ in 563 in group II having LDH level 600-800 IU/L and 1891+498 in group I having LDH level $<600 \mathrm{IU} /$ L. $^{28,29}$

\section{Complications}

Complications according to LDH level (IU/L)

It is found that abruption was seen in $20.48 \%$ in patients having $\mathrm{LDH}$ level $<600 \mathrm{IU} / \mathrm{L}$ and $22.22 \%$ having $\mathrm{LDH}$ level >600 IU/L.

Retinopathy was seen in $44.57 \%$ in patients having $\mathrm{LDH}$ level <600IU/L and $40.74 \%$ having $\mathrm{LDH}$ level $>600$ IU/L. Other complications are shown in Table 10.

$10.77 \%$ patient who died as a result of serious complications had higher LDH levels.

Qublan HS et al had found that in eclampsia was a complication of $4.7 \%$ of group II patients and $30.8 \%$ of group III. ${ }^{28,29}$ Abruptio placenta was seen in $15.4 \%$ of group III patients. Intracranial haemorrhage was seen in $7.7 \%$ of group III. HELLP syndrome was seen in $15.4 \%$ of group III patients. Acute renal failure was seen in $7.7 \%$ of group III patients. Pulmonary edema was seen in $7.7 \%$ of group III patients. DIC was seen in $7.7 \%$ of group III patients.

\section{CONCLUSION}

The present study was undertaken with the intention to study the clinical profile and laboratory investigation in severe preeclampsia and eclampsia, to know the maternal and perinatal outcome and its co-relation with $\mathrm{LDH}$ levels. 380 cases were studied in a span of 1 year i.e. August 2010 to July 2012. Amongst these, 260 (68.42\%) were eclampsia while $120 \quad(31.57 \%)$ were severe preeclampsia.

In the current study incidence of preeclampsia and eclampsia was found to be $1.03 \%$ and $2.23 \%$ respectively. The institute being a tertiary center has a higher referral rate which would probably account for this high incidence of eclampsia. $17.41 \%$ patients had glasgow coma scale less than 8 and mortality is also maximum in patient with glasgow coma scale of $<8$ (90\%), thus supporting the role of GCS as an important prognostic marker in predicting the maternal outcome. 
In majority of pre-eclampsia and eclampsia patients systolic blood pressure on admission was more than $150 \mathrm{mmHg}$ and diastolic blood pressure was more than $110 \mathrm{mmHg}$. Level of $\mathrm{LDH}$ was found to be significantly higher (more than $600 \mathrm{IU} / \mathrm{L}$ ) in pre-eclampsia and eclampsia patients. Complications were associated with high level of serum LDH and these were seen more in pre-eclampsia and eclampsia patients having serum $\mathrm{LDH}$ level more than 600IU/L.

Among 380 cases studied we found 17 patients of preeclampsia and 42 patients of eclampsia.15.52\% of patients were in HELLP syndrome. Vaginal delivery is commonest mode of delivery $72.50 \%$ in preeclampsia and $69.62 \%$ in eclampsia patients. In present study, it was found that poor perinatal outcome (in form of sick/IUD) was seen in majority of pre-eclampsia and eclampsia patients. The incidence of poor perinatal outcomes were significantly higher in pre-eclampsia and eclampsia patients with high level of serum LDH level (> 600IU/L).

Pre-eclampsia and eclampsia also affect birth weight of babies. Low birth weight was also found associated with high level of serum LDH levels in pre-eclampsia and eclampsia patients. Out of 120 patients of preeclampsia 12 patients died i.e. $10 \%$ and out of 260 patients of eclampsia 23 patients i.e. $8.85 \%$ died Delay in the referral leads to more number of convulsions prior to admission and lead to number of complications such as aspiration pneumonitis, ARF, CCF and cerebral hemorrhage could account for this high maternal mortality rate.

LDH level is a useful marker that reflects the severity and occurrence of complications of preeclampsia. Severe preeclampsia is frequently accompanied by evidence of hemolysis, which is semi-quantified by elevated serum lactate dehydrogenase levels and thus can be used as a marker to predict such outcomes.

Funding: No funding sources

Conflict of interest: None declared

Ethical approval: Not required

\section{REFERENCES}

1. Gabbe. Obstetrics: Normal and Problem Pregnancies. In: Hypertension. 5th ed. Churchill Livingstone, An Imprint of Elsevier; 2007.

2. Mattar F, Sibai BM. Eclampsia VIII risk factors for maternal morbidity. Am J Obstet Gynecol. 1990;163:1049-55.

3. Douglas KA, Redman CW. Eclampsia in the United Kingdom. British Med J. 1994;309(6966):1395-400.

4. Mabel L, Purkerson L, Verkerdi. History of Eclampsia, toxemia and Kidney in pregnancy. Am J Nephrol. 1999;19:313-19.

5. Craici I, Wagner S, Garovic VD. Preeclampsia and future cardiovascular risk: formal risk factor or failed stress test?. Ther Adv Cardiovasc Dis. 2008;2(4):249-59.

6. Banerjee S, Randeva H, Chambers AE. Mouse models for preeclampsia: disruption of redoxregulated signaling. Reprod Biol Endocrinol. 2009;7:4

7. Cadden KA, Walsh SW. Neutrophils, but not lymphocytes or monocytes, infiltrate maternal systemic vasculature in women with preeclampsia. Hypertens Pregnancy. 2008;27(4):396-405.

8. Kay HH, Zhu S, Tsoi S. Hypoxia and lactate production in trophoblast cells. Placenta. 2007;28:854-60.

9. Baweja S, Kent A, Masterson R, Roberts S, McMahon L. Prediction of pre-eclampsia in early pregnancy by estimating the spot urinary albumin: creatinine ratio using high-performance liquid chromatography. British J Obst Gynae. 2011;118(9):1126-32.

10. Boudava F, Cheli D. Eclampsia-epidemiological aspects and management of 28 patients. Tunis Med. 2008;86(7):685-8.

11. Tsoi SCM, Zheng J, Xu F, Kay HH. Differential expression of lactate dehydrogenase isozymes (LDH) in human placenta with high expression of LDH-A4 isozyme in the endothelial cells of pre-eclampsia villi. Placenta. 2001;22:317-22.

12. Bougneres PF, Rocchiccioli F, Nurjhan N, Zeller J. Stable isotope determination of plasma lactate conversion into glucose in fasting infants. Am J Physiol. 1995;268:652-9.

13. Burd LI, Simmons MA, Makowski EL, Meschia G, Battaglia FC. Placental production and foetal utilization of lactate and pyruvate. Nature. 1975;254:710-1.

14. Semenza GL, Roth PH, Fang HM, Wang GL. Transcriptional regulation of genes encoding glycolytic enzymes by hypoxia-inducible factor. J Biol Chem. 1994;269:23757-63.

15. Magee LA, Helewa M, Moutquin JM, Dadelszen P. Hypertension guideline committee, society of obstetricians and gynaecologists of Canada. prediction, prevention, and prognosis of preeclampsia. J Obstet Gynaecol Can. 2008;30(3):16-23.

16. Demir SC, Evruke C, Ozgunen FT. Factors that influences morbidity and mortality in severe preeclampsia, eclampsia and hemolysis, elevated liver enzymes, and low platelet count syndrome. Saudi Med J. 2006;27(7):1015-8.

17. Rivers EP. The clinical practice of emergency medicine. In: Preeclampsia, eclampsia, and other hypertensive disorders of pregnancy. $2^{\text {nd }}$ edition. Lippincott Williams and Wilkins; 1996:315-21.

18. Sibai BM. Eclampsia VI maternal and perinatal outcome. Am J obstet. Gynecol. 1990;163(3):104954.

19. Sibai BM, Sarinoglu C, Mercer BM. Eclampsia VII pregnancy outcome after eclampsia and long-term 
prognosis. Am J Obstet Gynecol. 1992;166(6):175761.

20. Mackay AP, Berg CJ, Atrash HK. Pregnancy-related mortality from preeclampsia and eclampsia. Obstet Gynecol. 2001;97(4):533-8.

21. Nodler J, Moolamalla SR, Ledger EM, Nuwayhid BS, Mulla ZD. Elevated antiphospholipid antibody titers and adverse pregnancy outcomes: analysis of a population-based hospital dataset. BMC Pregnancy Childbirth. 2009;9:11.

22. Vigil P. Maternal deaths due to eclampsia and HELLP syndrome. Int $\mathrm{J}$ Gynaecol Obstet. 2009;104(2):90-4.

23. Swain S, Ojha KN, Prakash A, Bhatia BD. Maternal and perinatal mortality due to eclampsia. Indian Pediatr. 1993;30(6):771-3.

24. Choudhary P. Eclampsia: a hospital based retrospective study. Kathmandu Univ Med J. 2003;1(4):237-41.

25. Bhagwanjee S, Paruke, Moodley J, Muckart DJ. Intensive care unit morbidity and motality from eclampsia. an evaluation of acute physiology and chronic health evaluation ii score and the glasgow coma scale score care. Crit Care Med. 2000;28(1):120-4.

26. Rinehart BK, Terrone DA, May WL, Magann EF, Isler CM, Martin JN. Change in platelet count predicts eventual maternal outcome with syndrome of hemolysis, elevated liver enzymes and low platelet count. J Matern Fetal Med. 2001;10(1):28-34.
27. JP Adam, Sayeba A. Perinatal outcome of eclampsia in Dhnka medical college hospital. Bangladesh J Obstet Gynaecol. 2008;23(1):20-4

28. Qublan HS, Ammarin V, Bataineh O. Lactic dehydrogenase as a biochemical marker of adverse pregnancy outcome in severe pre-eclampsia. Med Sci Monit. 2005;11(8):393-7.

29. Qublan HS, Ammarin V, Bataineh O, Shraideh Z, Tahat Y, Awamleh I, et al. Lactic dehydrogenase as a biochemical marker of adverse pregnancy outcome in severe pre-eclampsia. Med Sci Monit. 2005;11(8):393-7.

30. Wasim T, Siddiqui S, Gulli M. Eclampsia a major cause of maternal and perinatal mobidity and mortality, the professional. Ethiop J Health Sci. 2015;25(2):111-6.

31. Aali BS, Ghafoorian J, Alizadeh SM. Severe preeclampsia and eclampsia in Kerman, Iran, complications and outcomes. Med Sci Monit. 2004;10(4):163-7.

32. Markert CL, Shaklee JB, Whitt GS. Evolution of a gene: multiple genes for LDH isozymes provide a model of the evolution of gene structure, function and regulation. Science. 1975;189:102-14.

Cite this article as: Jharia J, Mathur P, Dave A, Mathur P. A prospective study to assess role of serum lactate dehydrogenase in prediction of adverse outcomes of pre-eclampsia and eclampsia. Int J Reprod Contracept Obstet Gynecol 2016;5:2522-9. 